\title{
Romantic Consumption: The Paradox of Fashionable Breath
}

\author{
Clark Lawlor
}

'I look pale. I should like to die of a consumption'. 'Why?' asked his [Byron's] guest. 'Because the ladies would all say, Look at that poor Byron, how interesting he looks in dying. ${ }^{1}$

Lord Byron, poetic superstar of the Romantic period, makes the notorious claim-only half-joking - to desire the killer disease of consumption of the lungs. This assertion presents several problems, or perhaps opportunities, for a volume dedicated to the subject of breath. Consumption was the main disease of the lungs for people in the Romantic period and for the nineteenth century in general. ${ }^{2}$ There were others, but they received nowhere near as much attention either in the medical literature or in wider representation and narrative. For the wildly popular Bryon, and for many of his contemporaries, consumption was a disease that conferred a certain social-even sexual — cachet, and the same was true for 'the ladies', albeit framed according to conventions of gender.

\footnotetext{
C. Lawlor $(\otimes)$

Department of Humanities, University of Northumbria, Newcastle upon Tyne, UK
}

(C) The Author(s) 2021

D. Fuller et al. (eds.), The Life of Breath in Literature, Culture

and Medicine, Palgrave Studies in Literature, Science and Medicine, https://doi.org/10.1007/978-3-030-74443-4_14 
Consumption was fashionable, even amongst some of the lower classes, or 'orders' as they were known before the Industrial Revolution at the end of the eighteenth century. The status of breath within the construction of this disease, however variously manifested in different social groups (striated according to gender, class, ethnicity, religion, and race), is key to explaining how such a paradoxical phenomenon came to be. Breath, as most of the essays in this volume show, is not just a biological entity, not merely a physical process. The full force of literary, artistic, philosophical, economic, and social representations and narratives comes into play when breath is experienced by individual human subjects. If we want to understand our experience of breathing we had better consider our own templates for the experience of disease and health, and some of those templates include belles lettres, creative literature, and works of art (both high and low). ${ }^{3}$ As this essay will show, for some conditions and entities, breath being prime among them, we need a long historical view of the sort taken in this volume in order to comprehend the function of breath in our lives and-potentially-how to deal with it better in both the clinic and the wider context of the social worlds in which we, 'all the breathers on this star', move. ${ }^{4}$

We must not forget that we are dealing with a disease of the breath before we turn to the apparently counter-intuitive phenomenon of consumption as a Romantic fashion. An explanation of some basic features of what was understood to be a consumption of the lungs is in order. The collection of symptoms associated with consumption remained mostly static even after the scientific revolutions that displaced the humours as the core medical theory. We see some of the spiritual connotations of breath as life, as ruach, as divine inspiration and communication in A. A. Long's essay, and as conspiration and co-breathing, as expounded by Phillip Horky, but here we must first focus on breath as death, as disease, as the destruction of the lungs. This is, in the physical world, conspiration gone wrong, failing, and-as often, in the case of this richly symbolic process-leading to religious assumptions about moral failure.

We can take as our starting point a horrific passage from the novel Liberty Hall, Oxon. (1860) by the atheist and iconoclast William W. Reade. Reade rejected the idea of the Christian good death, prevalent in his age, stemming from the medieval concept of the ars moriendi, or art of dying well. Reade takes the symptoms of consumption of the lungs, or pulmonary tuberculosis, as the dramatic basis of a distinctly bad death: 
Her body was bent forward on her knees; the joints of this body so thin, that it was almost deformed, were swelled and red and painful. She laboured and coughed for her breath; each time that she breathed she coughed up blood ...

But while they were still gazing at her, they saw the colour fade from her cheeks, the smile from her lips. Her face, with wonderful rapidity, became sallow and dusky; her lips and her finger-nails tinged with blue. Her breathing became rapid, and was expelled in sharp and hurried gasps. Long, deep streams of perspiration ran down her face; her features assumed an expression of anxiety, her eye-balls protruded, and her heart throbbed savagely and loudly. 5

The beatific 'smile' of the willing Christian giving up the soul to God, the gentle and measured breathing, the calm acceptance of death and the afterlife in the set-piece good death of the Victorian era, are replaced here with shocking speed by 'anxiety' and its attendant physical symptoms, such as 'rapid' breathing (which is also part of the consumptive's difficulty in breathing), blood mingled with the very breath itself, sweat, and tachycardia. Reade's prose reflects this shift in the paragraph, with the even tripartite rhythm of the first sentence descending into the disrupted central sentence that mimics the staccato gasping for breath of the heroine. Here breath is not an isolated physical phenomenon: it interacts with the other physical and mental systems to manifest an holistic experience rather than a monological process. Breath here signifies the death of spiritual hope, the failure of Christian faith, and the subject's realisation of this fact, as well as the body's disintegration via the lungs.

The facts of pulmonary tuberculosis as we presently understand them give us necessary information on how to read the disease process itself, although we should not consider this tuberculosis bacterium separately from its social contexts, but simultaneously. Before Robert Koch discovered the tubercle bacillus in 1882, 'consumption' was a term that covered a range of wasting conditions that (the clue is in the name) consumed the lungs and the body's flesh. Koch found that consumption was due to an infectious germ, a bacterium that travelled through the air and the breath and attacked the lungs when activated. Lesions or tubercles were manufactured in the lungs and destroyed the lung tissue, either slowly in a 'decline', or quickly in a 'galloping' consumption. Before the arrival of streptomycin for clinical use in 1946, a confirmed consumption was regarded as a death sentence, most famously in the case of the Romantic poet, John Keats. 
The 'narrative' that consumption follows partly determines the different ways it has been constructed in human experience and representation: at first it can be mild, and the cough may seem like that of a cold or minor irritation. Then the sufferer can lose weight, appetite, be pale or flushed with a 'hectic fever' and night sweats. As things become worse, the patient can become skeletal, tortured with a never-ending cough, and bring up blood and fetid, stinking matter from the lungs. One end to this narrative is the patient choking to death on disintegrated lungs, a fate possibly made worse by the fact that the sufferer is entirely compos mentis throughout. ${ }^{6}$

This was one 'reality' of consumption, and one that was modelled in the humoral theory that underpinned representations of consumption from the classical period to the 'long' eighteenth century, the point at which the theory of the humours was discarded in favour of mechanicalhydraulic notions of the body and ideas giving an enhanced role to the nervous system, although not the nervous system we have today. According to humoral theory, the lungs were corroded by pus from the nodes or ulcers created by bad blood stagnating in the lungs. The putrid humour-often thought to be caused by the dregs of food from malfunctioning digestion-was understood to rot the lungs and, consequently, waste the body. ${ }^{7}$ As the Welsh cleric Rowland Watkyns (ca. 1614-64) put it in his Flamma sine Fumo: or, poems without fictions (1662):

The Consumption.

Foul humors do descend: thin and sharp rume

Fall from the head, and doth the Lungs consume.

Short cough, short breath, and faintness, never cease

To be companions of this sad disease. ${ }^{8}$

Hence the core imagery associated with the classical and early modern consumption of the lungs, drawn from the medical model, was disgusting decay caused by 'foul humours'.

Christopher Bennet's popular Theatrum tabidorum (1656) described the wasted lungs of the consumptive in terms of their excremental quality, ${ }^{9}$ while the famed eighteenth-century Dutch physician Gerard van Swieten could hardly stand the vicious stench of the fetid product of a consumptive's cough. ${ }^{10}$ The equation of the stinking breath of the consumptive with sin was an easy one for early modern authors to 
make, and the influential Enlightenment anatomist Gianbattista Morgagni's description of a consumptive prostitute did nothing to dispel the symbolism: 'This woman had thrown up pus by expectoration, and had been long macerated with a slight fever, from a venereal cause; so that in the body after death, no traces remained of her breasts, but the nipples only were discerned'. ${ }^{11}$ So repulsive were the potentially contagious dregs and vapours emitted by the decomposed lungs of consumptives that many physicians were afraid to perform anatomies on those who had perished.

Humoral theory would die out during the course of the seventeenth and eighteenth centuries, but the moral imagery of sin and filth continued on into the nineteenth. Dr Burney Yeo observed that 'Sir William Gull has said that he can smell syphilis. I think I can smell phthisis. There is a peculiar nauseating odour in the breath'. ${ }^{12}$ Phthisis was the Greek term for consumption, and commonly used from classical times onwards. The smell of the breath was an invisible marker for physical and moral corruption, just as marks on the skin, in diseases like smallpox or the bubonic plague, could be understood as visible signs of immorality.

The morality of consumptive breath is made abundantly clear in the eighteenth-century novel too, most notably in the bad death of the libertine Thomas Belton in Samuel Richardson's compendious novel, Clarissa. Belton's consumptive death is in stark contrast to Clarissa's, and is a powerful instance of the ways in which one disease (or actually set of diseases in the eighteenth century, as there were different forms of consumption) can have divergent narratives, symptomatologically and morally. Belton's horrific death presages the pains of hell that await his rapist friend and the villain of the novel, Lovelace:

$\mathrm{He}$ is now at the last gasp-rattles in the throat-has a new convulsion every minute almost! What horror he is in! His eyes look like breathstained glass! They roll ghastly no more; are quite set: his face distorted and drawn out by his sinking jaws, and erected, staring eyebrows, with his lengthened furrowed forehead, to double its usual length, as it seems. It is not, it cannot be, the face of Belton, thy Belton and my Belton. ${ }^{13}$

If the good death must be in the classical bodily mode, to deploy Mikhail Bakhtin's term, this bad one is most certainly in the grotesque, in which the body's boundaries are well and truly traversed and 'distorted'. 14 Belton's breath has become a death-rattle, less a living breath than a 'convulsion', a spasm, a form of torture. The eyes are windows to the soul, 
and here that soul is 'breath-stained glass', which depicts both the departure of the soul to domains less-than-holy, and the moral confusion and fog that has characterised Belton's sinful and rakish life.

These depictions of consumptive breath as malfunctioning, rotting, stinking, arhythmical, failing, and dying are bound up with various discourses that combine to create the different forms of representation that we have seen thus far. However, these were not the only possibilities for the representation and experience-both are mutually informing-of consumptive breath.

\section{Fashionable Consumptive Breath}

As we saw in the opening quotation of Byron's words, consumption and its concomitant breath could be viewed in almost the opposite way. Dr Thomas Beddoes (1760-1808) commented on the popular literary representation of consumption that had become prevalent by the end of the eighteenth century in his Essay on the Causes, Early Signs, and Prevention of Pulmonary Consumption (1799):

Writers of romance (whether from ignorance or because it suits the tone of their narrative) exhibit the slow decline of the consumptive, as a state on which the fancy may agreeably repose and in which not much more misery is felt, than is expressed by a blossom, nipped by untimely frosts. Those who only see the sufferers in passing, are misled by the representation.

And I have heard many persons thus prepossessed, after closely attending a sick friend, declare their surprise not less than their horror, at the unexpected scenes of varied and protracted misery which they have been condemned to witness. ${ }^{15}$

The second paragraph chimes better with the kind of consumption in which 'horror' is a key term. The first paragraph cites the imagery of wilting and dying flowers so frequent in literary descriptions of consumption, a comparison that reduces the breathless gaspings of dying consumptives and replaces them with the narrative of a 'slow decline' (and 'decline' was commonly substituted for the word consumption itself in both literature and life). In Beddoes' disapproving professional view, the demands of literary genre appear to overrule the need to be truthful about the effects of this deadly disease. 
Beddoes was a political radical who supported the French Revolution, a materialist (this ungodly attitude probably prevented him from gaining a Chair in Chemistry at Oxford University), and was not amenable to Romantic and/or Christian interpretations of consumption as a blessed or glamorous disease. For Beddoes, the mind was not separate from the body, and his efforts to determine the life-giving role of breath were confined to his experiments at his Pneumatic Institution in Bristol, a city that, like Bath, was a fashionable resort for consumptives. The newfound field of pneumatic medicine, itself stimulated by the discovery and isolation of major gases such as carbon dioxide, hydrogen, and oxygen between 1754 and 1774, gave hope that cures for diseases such as consumption (a major killer at the time) might be found. If the interaction of chemistry and physiology could be understood, via experiments in combustion in particular, then the way might be clear for the process of respiration to be demystified.

For Beddoes and the materialists, consumptive breath was a physical phenomenon to be eliminated by empirical science, and the matter of a transcendent soul, spirit, and its relationship to God or some form of pantheistic 'One' was beyond their remit, notwithstanding Beddoes' friendship with writers like Samuel Taylor Coleridge, who certainly were interested in metaphysical and religious issues as well as in experimenting with Beddoes at his Pneumatic Institute. ${ }^{16}$

We need to understand how it can be that there were two such divergent discourses of consumptive breath. To do this we need to take a long-historical view. Previous essays in this volume discuss the Galenic notion of the lungs as a kind of bellows in which the 'natural spirits', the innate form of the vivifying pneuma, transported by the blood from the liver and then heart to the lungs, is further refined (via further pneuma drawn from the air by the lungs) into 'vital spirits', a higher form of pneuma. ${ }^{17}$ Symbolically and literally, breath was life. These classical ideas of a vital spirit that animated the body translated easily in Christian contexts as the divine spark of the soul. ${ }^{18}$

If we fast-forward to nearer the time of the Romantics, we can see how the idea of consumptive breath plays out in a Protestant Christian context inflected by gender and genre. Clarissa represents consumptive breath in surprisingly positive ways, given the moral example of Belton. The eponymous heroine is raped by the rake Lovelace and develops a 'nervous consumption' as a result: 
I don't think I am dying yet—not actually dying, Mrs. Lovick—for I have no bodily pain-no numbnesses; no signs of immediate death, I think.And my breath, which used of late to be so short, is now tolerable, my head clear, my intellects free-I think I cannot be dying yet ... yet how merciful is the Almighty, to give His poor creature such a sweet serenity! 'Tis what I have prayed for! ${ }^{19}$

Clarissa embodies the tradition of the Christian 'good death' from consumption, which is based on the idea of the disease as so symptomless that one scarcely knows one is dying, or even has contracted the disease. Clarissa embraces death in a Neo-Platonic displacement of thwarted secular and sexual love, redirecting her libidinal energies towards Christ.

Consumption was thought to be a 'Golden Disease' (John Bunyan's term) in this context: it left one's mind clear to make one's peace with God and man; was usually chronic, so one had time to accomplish one's repentance and arrange one's estate; and the shedding of the flesh and lack of scarring or marks on the skin symbolised the notion that one was also shedding one's sins and rising to the afterlife with divine approval. It was no doubt a help that the notion of consumptives as beautiful had persisted from the Ancients: according to the scornful Aristides (fl. 160 $\mathrm{AD})$, there was a myth that the phthisical were 'comely', 'and that they have many admirers ... while those who are in excellent health and whose beauty is in high esteem are inferior to them'. ${ }^{20}$ Clarissa can truly 'pray for' such a holy disease. Her speech becomes progressively less breathless, less frequently punctuated by dashes, commas, and semicolons, until she arrives at the ecstatic and ringing final sentence that confirms her triumph over both death and breathlessness: 'Tis what I have prayed for!'.

Clarissa's, and later representations of the good death, are fed by the famous example of the poet John Donne's holy (and eccentric) death from consumption, especially as narrated in Izaak Walton's hagiographical 'Life of John Donne', in which he looked so thin that he seemed like a living memento mori, and was said to have been preaching his own funeral sermon. ${ }^{21}$ The ease of the consumptive death in this discourse is crucial for Romantic ideas of breath. Thomas Browne's (1605-82) description of his consumptive friend's death in 'A Letter to a Friend, upon the occasion of the Death of his Intimate Friend' was a great influence on the attitudes of the following two centuries in Britain and America: 
his soft departure, which was scarce an expiration; and his end not unlike his beginning ... and his departure so like unto sleep, that he scarce needed the civil ceremony of closing his eyes; contrary unto the common way, wherein death draws up, sleep lets fall the eye-lids. ${ }^{22}$

This seductive vision of a 'soft departure' for the devout Christian was reinforced by popular and specialist medical texts. Of particular relevance to Clarissa is the pronouncement in William Buchan's best-selling and long-running manual of Domestic Medicine that 'a Nervous Consumption is a wasting or decay of the whole body, without any considerable degree of fever, cough, or difficulty of breathing. It is attended with indigestion, weakness, and want of appetite etc.' and affects 'those who are of a fretful temper'. ${ }^{23}$ The lack of 'difficulty with breathing' is key here: it was apparently possible for some consumptions to act as what we might now think of 'silent' pneumonias, with very little evidence of their presence. Even if one did not have a 'nervous consumption', a category that chimed well with the later eighteenth-century emphasis on the nervous system, one might still not be aware that consumption was upon one, hence the classical concept of the spes phthisica, described by the Greek physician Aretaeus:

haemorrhage from the lungs is particularly dangerous, although patients do not despair even when near their end. The insensibility of the lungs to pain appears to me to be the cause of this, for pain is more dreadful than precarious; whereas in the absence of it, even serious illness is unaccompanied by the fear of death and is more dangerous than dreadful. ${ }^{24}$

Because the lungs have fewer nerves than other parts of the body, the pain of consumption is minimised, so the trajectory of the disease as a silent assassin becomes possible.

Clarissa's death seems very like Browne's friend's 'soft death', and the breath is a key part of the process: 'her aspect was sweetly calm and serene; and though she started now and then, yet her sleep seemed easy; her breath indeed short and quick; but tolerably free, and not like that of a dying person' (Vol. 7, Letter CV, 412). This was the point: consumption could, in the Christian 'good death', and in the classical spes phthisica, evade the appearance of death itself, even in terms of breath.

This kind of representation of beautiful dying women was not confined to the pages of literature. We see the interaction between literary and 
visual works and real-life encounters between patient and physician, and the wider network of people around that, in operation in the burgeoning age of sensibility. In 1778 Dr Erasmus Darwin, physician and poet, treated the 'lovely' Lady Northesk for consumption. This incident was described by her friend, the poet Anna Seward, in her Memoirs of $\mathrm{Dr}$ Darwin, and by Sir Walter Scott in the preface to Seward's Works:

Lady Northesk lay on a couch through the day, in Dr Darwin's parlour, drawing with difficulty that breath, which seemed often on the point of final evaporation. She was thin, even to transparency; her cheeks suffused at times with a flush, beautiful, though hectic. Her eyes remarkably lucid and full of intelligence. If the languor of disease frequently overshadowed them, they were always relumined by every observation to which she listened, on lettered excellence, on the power of science, or the ingenuity of art. ${ }^{25}$

As Clarissa's death demonstrates, Northesk would not be out of place in a sentimental novel, at least in Seward's description. Like her breath, Seward's friend's body seems so slender as to be about to achieve 'final evaporation', conspiring, or perhaps translating, into the ideal spirit of the Christian tradition, soon to be converted into the 'infinite One' of the Romantics. Not only is breath the Soul, but it is also the Body.

Consumption had been linked with male genius from classical times: Aretaeus in particular made an influential pronouncement on the nature of the consumptive in his On the Causes and Symptoms of Chronic Diseases. Consumptives tended to be young, thin, pale, and distinguished by 'eyes hollow, brilliant and glittering'. ${ }^{26}$ Apart from the cough, they might be feverish, and this 'ardent fever' could burn away the humours in which 'formerly they were immersed ... as if in mud and darkness; but when the disease has drained these off, and taken away the mist from their eyes, they perceive those things which are in the air [spiritual presences of the dead], and with the naked soul become true prophets' (Aretaeus, 273). Now 'every sense is pure, the intellect acute, the gnostic powers prophetic' (272-73). Unfortunately, death was the price to pay for achieving 'such a degree of refinement in their humours and understanding', 'the vital power having been already evaporated into air' (273). Lady Northesk is a long way from the time of Aretaeus, but the notion of breath as vital power, rewritten as defining the Christian soul, persists in Anna Seward's glamorous depiction of her friend. Seward-a bluestocking-was also concerned to adapt the masculine tradition of consumptive genius for 
Northesk, a tradition we see in full operation with the arrival of the consumptive Romantic author, and especially the poet.

\section{Alastor and Romantic Death-Fashionable Breath}

By the Romantic period, the paradigm of the nervous system as the dominant medical theory of the body was fully accepted, and underpinned the physical notions of 'Sensibility' and its concomitant moral concept of the 'Sentimental'. The hydraulic-mechanical thinking of the earlier part of the century had modulated into an idea of the human body that focused on the nerves, conceived broadly as vibrating strings that could transmit sensory inputs of all types to the brain, and thus affect that body, often without the direct intercession of the conscious mind. 'Sensibility' was the capacity of the body and mind to process external stimuli. The upper classes or 'orders' and intellectuals were thought to be naturally more refined, with literally thinner nerves, and women especially so.

To have too much sensibility was both a badge of honour and a problem. Blushing and fainting heroines abounded in the novel: psychological conflict would inevitably play itself out directly on the body in this model, as Gillian Skinner demonstrates here in the context of breath and breathlessness in the novel of sensibility. The old tradition of love melancholy found new energy in nerve medicine: now a heart could be broken by the relays of the nerves which transmitted emotions to the entire system, of which the heart was a part. Consumption was a common result of such nervous trauma: poets wasted away pining for their mistresses, while heroines like Clarissa shed their flesh in response to thwarted love and eventually, in her case, abduction and rape. As the influential Scottish physician of the nerves Robert Whytt (1714-66) argued, 'a phthisis pulmonalis may also be the consequence of nervous disorders, when the morbid matter producing them falls chiefly upon the lungs' ${ }^{27}$ Even before this, another famous Scot, George Cheyne, had connected consumption with hyper-sensible and sensitive poets as well as with the beautiful people identified as likely to be consumptives in the classical tradition: 'I have always foretold, that these Symptoms (especially in tender, delicat, lively young Persons) would terminat in a real sensible Phthisis Pulmonum'. If Cheyne could treat the nervous disease early on, consumption might be prevented and thus preserve 'some of the noblest and brightest Spirits this Age or Country produces'. ${ }^{28}$ 
Nerve medicine took another turn at what is usually seen as the beginning of the Romantic period in British literature, when the ideas of Edinburgh physician John Brown (1735-88) took hold in the medical and popular-literary imagination, persisting a long time after they had been exploded in the professional medical sphere. 'Brunonianism' argued that each person had a limited amount of 'excitability' or life-force, like a battery, and that to remain healthy this needed to be stimulated at the correct level, no more and no less. Either overstimulation (sthenia) or understimulation (aesthnia) would cause general problems that manifested themselves as localised symptoms. Cure might consist of applying stimulating substances when the person was under-stimulated, and 'lowering' methods when over-stimulated.

In the case of consumption of the lungs, Brown considered the tubercles to be a side-effect of blockages produced by disease of the whole system, the lungs being more directly susceptible to inflammation than other parts of the body because of their immediate contact with air. A 'general consumption' or 'tabes' was an overall wasting of the body. Literary and artistic types, especially poets, were liable to overwork their mental energies and their bodies at the same time: 'excess in thinking, by wasting the excitability, ends in indirect indebility'. ${ }^{29}$ As the nowminor but contemporarily popular consumptive poet Henry Kirke White observed, 'My mind is of a very peculiar cast.-I began to think too early, and the indulgence of certain traits of thought, and too free an exercise of the imagination, have superinduced a morbid kind of sensibility, which is to the mind, what excessive irritability is to the body'. ${ }^{30}$ All one's vital energy could be drained to the lees, and even result in death. Love melancholy, often the resort of the male poet (but certainly not confined to him), was also a prime route for consumption of the vital energy leading to a literal consumption.

The discourses of the consumptive good death, love melancholy, and poetic genius coalesce in the dying breath of Percy Shelley's poetic creation Alastor; or, the Spirit of Solitude (1815). ${ }^{31}$ This poem describes the archetypal, semi-autobiographical figure of the questing consumptive poet, whose search for the unattainable love object (which can be a facet of himself in a more narcissistic and even masturbatory interpretation of the quest) ends in his death. ${ }^{32}$ Here, breath is a complex amalgam of religious, secular, and scientific long-historical discourses as well as contemporary ideas about the (male) poet, and the function of poetry in society, and medicine. ${ }^{33}$ 
Shelley was directly influenced by Brunonian theory and, in his poem Queen Mab, had noted the deleterious effects of excessive sensibility in a medical case. ${ }^{34}$ Dr Thomas Trotter, a well-known theorist of the modern nervous system and its ever-more severe effects on civilised society, warned in A View of the Nervous Temperament (1807) of the 'corroding sorrows' of passion sporting with the constitution of one who feels 'sensibility to excess': such a 'degree of feeling ... loves and hates beyond all bounds'. ${ }^{35}$ Trotter himself had helped promulgate the popular notion that fashionable contemporary lifestyles would lead to the fashionable nervous diseases of the upper 'orders' trickling further down to the middling ones, and perhaps even lower than that, leaving the masculine vigour of the British in a parlous state.

In Alastor, Shelley depicts the poet as unable to cope with the stresses and strains of the world, so full of sensibility is he, so prone to living fast and dying young in the Brunonian conception of poets burning like comets. In his climactic death scene, Alastor is
A fragile lute, on whose harmonious strings
The breath of heaven did wander - a bright stream
Once fed with many-voicèd waves-a dream
Of youth, which night and time have quenched for ever,
Still, dark, and dry, and unremembered now. (667-71)

The 'breath' of the heavenly wind is not so much, as elsewhere in Shelley's writing, a symbol of the pressures of existence in the modern world, particularly the traumas of lost love, or love unable to be realised, or even poetic achievement in the cruel environment of a seemingly capitalised and brutal market for literature. At this point in the poem these external forces have done their work, and Alastor is at the end-stage of his poetic and glamorous consumption. Only those who lack sensibility can survive in the harsh world, so Shelley's 'fragile' poet-figure is tragically doomedadmittedly, to a beautiful death. Alastor's death arrives via consumption: he wastes away (the word 'waste' is repeatedly used in different forms) as his vital force is 'exhausted' by his incessant search for a seemingly unreachable number of goals, including his ideal woman, sexual plenitude, poetic perfection, and a blissful state of mystical oneness with the universe. This might seem a great deal to ask of the quest, but nevertheless this is Alastor's mission, and it understandably proves to be too much for his reserve of life-fuel. 
The burnt-out Alastor adopts a suitably dramatic pose in this death scene, the masculine and more secular equivalent of Clarissa's beautiful good death:

He did place

His pale lean hand upon the rugged trunk

Of the old pine. Upon an ivied stone

Reclined his languid head, his limbs did rest,

Diffused and motionless ... (632-36)

Now Alastor moves beyond earthly, physical encumbrances, in the manner of the consumptive Christian good death, especially as it had evolved in the late eighteenth and early nineteenth centuries, where an emphasis on the struggle with the Devil at the point of death had diminished as a part of the mild secularisation of death for the mainstream Christian. ${ }^{36}$ Of course Shelley has no truck with the Christian good death as such, but he does adapt it for his secular and Romantic vision of the dying and wasted poet:

\section{no mortal pain or fear}

Marred his repose, the influxes of sense, And his own being unalloyed by pain, Yet feebler and more feeble, calmly fed The stream of thought, till he lay breathing there At peace, and faintly smiling:- -his last sight

Was the great moon, which o'er the western line

Of the wide world her mighty horn suspended,

With whose dun beams inwoven darkness seemed

To mingle. Now upon the jaggèd hills

It rests, and still as the divided frame

Of the vast meteor sunk, the Poet's blood,

That ever beat in mystic sympathy

With nature's ebb and flow, grew feebler still. (640-53)

Alastor's breath is peaceful and 'smiling', a quiet acceptance of death and a release from the woes of the world: he is in 'mystic sympathy' with nature, and surely here we must think of co-breathing or conspiration as reworked for Shelley's particular Romantic context. If blood beats in sympathy with 'nature's ebb and flow', so too does his breath.

The following lines push this conspirational and consumptive process even further: 
And when two lessening points of light alone

Gleamed through the darkness, the alternate gasp

Of his faint respiration scarce did stir

The stagnate night:- - till the minutest ray

Was quenched, the pulse yet lingered in his heart.

It paused-it fluttered. (654-59)

The synchronicity of 'pulse', breath, and natural phenomena draws the poem towards its quietly dramatic conclusion, in which breath is life. 'The alternate gasp' hovers at the end of the line, as poetic rhythm enacts Alastor's final breaths - the 'faint respiration' fluttering like the pulse, about to cease. This is not the stinking breath of the sinful consumptive, the humoral or mechanical condemnation of fleshly and spiritual weakness. A new, Brunonian model, emerging from a vitalist conception of physical sensibility, gives Shelley the platform for a spectacular representation of the tragic poet, a figure who is a projection in part of himself, or at least an experiment in the possibilities available to a poet in this turbulent period.

Alastor finally presents us, after more description of his languorous dying minutes, with a vision of the poet-as-breath, 'fled / Like some frail exhalation' (687). Shelley's redeployment of the Christian consumptive narrative in a depiction of union with a Neo-Platonic Oneness retains the equation of breath with Soul, but overdetermines breath, giving it a quasiorgasmic quality as well as a more radical political aspect. The identity of the over-reaching, Promethean poet is a familiar one, and the inevitability of his death due to the exhaustion of a fixed life-force is also enacted in the 'frail exhalation' at the end of his life.

\section{Conclusions}

Breath, we have found, is not merely a physiological process. In human culture, breath can be experienced and represented in startlingly different ways, even within the same disease and the same period. The stinking 'reality' of consumptive breath can be, and was, overridden, overwritten, or reframed by cultural discourses that prioritised other functions over the mere transfer of air into and out of the body. In order to understand breath in the Romantic period, it is necessary to examine vestigial religious and classical concepts of breath, new and old medical models-and, one might add, issues of gender, rank, and ethnicity. 
By tracing the interaction between the diverse components that make up the fashionable Romantic representation of consumptive breath, we gain a more precise understanding of breath and its relationship to human experience in this period. We also find that breath is historically specific: how else can we explain the extreme divergence between the 'unexpected scenes of varied and protracted misery' caused by consumption, the heroine who 'laboured and coughed for her breath; each time that she breathed she coughed up blood', and the desire of Byron to attract the ladies by contracting consumption, or Alastor, 'breathing there / At peace, and faintly smiling'? Breath in our own time also deserves such attention: without a comprehension of its cultural meanings, we will find it more difficult to treat inside or outside the clinic, as Katharine Craik and Stephen Chapman also argue in this volume. Put another way, a breath is not separate from the social world of the person who breathes it.

\section{Notes}

1. The Journal of Thomas Moore, 1826-1830, ed. by Wilfred S. Dowden, et al., vol. 3 (Newark: University of Delaware Press, 1986), 1120. Entry dated 19 February [Tuesday] 1828.

2. See Clark Lawlor, Consumption and Literature: The Making of the Romantic Disease (Basingstoke: Palgrave, 2006).

3. This approach is taken up by Arthur Rose, et al., Reading Breath in Literature (Basingstoke: Palgrave, 2019).

4. Quotation from the Scottish working-class poet David Gray, who wrote a sonnet sequence, 'In the Shadows', about his experience of poetic consumption, fully conscious of the fate of Keats and a genealogy of other consumptive male poets: In the Shadows, Poems by David Gray with Memoir of His Life (Boston, MA: Roberts Brothers, 1864), 158.

5. William W. Reade, Liberty Hall, Oxon., 3 vols (London: C. J. Skeet, 1860), vol. 3, 323, 327.

6. Thomas Dormandy, The White Death: A History of Tuberculosis (London: Hambledon Press, 1999), 22-23.

7. For digestion in the humoral model, see Ken Albala, Eating Right in the Renaissance (Berkeley: University of California Press, 2002), 57.

8. Flamma sine Fumo: or, poems without fictions. Hereunto are annexed the Causes, Symptoms, or Signes of several Diseases with their Cures, and also the diversity of Urines, with their Causes in Poetical measure (London: William Leake [etc.], 1662), 11. 163-66.

9. Christopher Bennet, Theatrum Tabidorum (London: Thompson, 1656), cited in Gerard van Swieten, Commentaries Upon Boerhaave's Aphorisms 
Concerning the Knowledge and Cure of Diseases, 18 vols (Edinburgh: Charles Eliot, 1776), vol. 12, 131.

10. Gerard van Swieten, Commentaries Upon Boerhaave's Aphorisms, vol. 12, 130 .

11. Gianbattista Morgagni, The Seats and Causes of Diseases, Investigated by Anatomy, 3 vols, trans. Benjamin Alexander (London: A. Millar, et al., 1769), 1, 652. See also Matthew Baillie, The Morbid Anatomy of Some of the Most Important Parts of the Human Body (London: J. Johnson, 1793), 48-49.

12. Burney I. Yeo, 'On the Results of Recent Researches in the Treatment of Phthisis', British Medical Journal, 1877, 1(841), 159-60, 195-97 (quotation on 196). See also G. L. Bayle, Researches on Pulmonary Phthisis, trans. by William Barrow (Liverpool: Longman, et al., 1815), 125 .

13. Samuel Richardson, Clarissa, or, the History of a Young Lady, 3rd edn, 8 vols (London: S. Richardson, 1751), Letter LV, vol. 7, 192.

14. For a sophisticated analysis of Bakhtin's concepts of the classical and grotesque bodies, see Peter Stallybrass and Allon White's influential The Politics and Poetics of Transgression (London: Methuen, 1986).

15. Thomas Beddoes, Essay on the Causes, Early Signs, and Prevention of Pulmonary Consumption for the use of Parents and Preceptors (Bristol: Longman and Rees, 1799), 6.

16. For a useful summary of Beddoes' relationship to Romantic Medicine, see Neil Vickers, 'Coleridge, Thomas Beddoes and Brunonian Medicine', European Romantic Review 8/1 (1997), 47-94. Sharon Ruston has published a great deal on the relationship of Humphry Davy and his circle to pneumatic medicine and literature, and has argued that Romanticism was created by wider discourses than the literary and narrowly philosophical. See Sharon Ruston, Creating Romanticism: Case Studies in the Literature, Science and Medicine of the 1790s (Basingstoke: Palgrave Macmillan, 2013), 16-20.

17. See the essays in this volume by Carole Rawcliffe and Corinne Saunders, which give differently nuanced accounts of this interpretable and fragmentary material, reported partly from Galen and partly from later traditions of Galenic medicine.

18. Bruno Meinecke, Consumption (Tuberculosis) in Classical Antiquity (New York: Paul Hoeber, 1927). As Patrick Gray shows here, the relation of breath to soul in the early modern period was a matter of debate, as it was later when materialism became stronger as a philosophical and scientific movement.

19. Richardson, Clarissa, Letter XCI, vol. 7, 354.

20. Meinecke, Consumption (Tuberculosis) in Classical Antiquity, 389. 
21. The Lives of John Donne, Sir Henry Wotton, Richard Hooker, George Herbert and Robert Sanderson, 4th edn, 1675, intro. by George Saintsbury (London: Oxford University Press, 1927).

22. 'A Letter to a Friend, Upon the Occasion of the Death of His Intimate Friend', in Sir Thomas Browne: Religio Medici and other Works, ed. by L. C. Martin (Oxford: Clarendon Press, 1964), 177-96, at 180-81; originally published posthumously in London, 1690.

23. William Buchan, Domestic Medicine: Or, a Treatise on the Prevention and Cure of Diseases by Regimen and Simple Medicines (Dublin: Saunders, et al., 1774), 125.

24. The Extant Works of Aretaeus, The Cappadocian, repr., $1856 \mathrm{edn}$, ed. and trans. by Francis Adams (Boston, MA: Longwood Press, 1978), 'On the Causes and Symptoms of Chronic Diseases', Bk. 1 Ch. 8, 'On Phthisis', 269.

25. Anna Seward, Memoirs of Dr Darwin (London: J. Johnson, 1804), 10910.

26. The Extant Works of Aretaeus, 'On Phthisis', 309-12.

27. Robert Whytt, Observations on the Nature, Causes and Cure of Those Disorders Which Have Been Commonly Called Nervous, Hypochondriac, or Hysteric, 2nd edn (Edinburgh: J. Balfour, 1765), 237.

28. George Cheyne, The Natural Method of Cureing the Diseases of the Body, and the Disorders of the Mind Depending on the Body (London: G. Strahan, 1742), 185-87, 'A Consumption'.

29. John Brown, Elementa Medicinae (Edinburgh: n.p., 1770, trans. 1795), i. 125 .

30. To Leeson, from Nottingham, 7-4-1806, in Charles Vernon Fletcher's 'The Poems and Letters of Henry Kirke White: A Modern Edition', 3 vols (Ph.D. diss., University of Nottingham, 1980), vol. 3, 890. See also the Remains of Henry Kirke White, 2 vols (London: Robertson, 1824), vol. 2,46 .

31. References to Alastor are from The Complete Poetry of Percy Bysshe Shelley, vol. 3, ed. by Donald H. Reiman, et al. (Baltimore: Johns Hopkins University Press, 2012), 7-30. For a wider consideration of the role of breath in Romantic poetry, see Francis O'Gorman, 'Coleridge, Keats, and The Science of Breathing,' Essays in Criticism: A Quarterly Journal of Literary Criticism 61/4 (2011), 365-81; Andrew Kay, 'Conspiring with Keats: Toward a Poetics of Breathing', European Romantic Review 27/5 (2016), 563-81; Thomas H. Ford, Wordsworth and the Poetics of Air (Cambridge: Cambridge University Press, 2018).

32. Monika Lee, "'Happy Copulation": Revolutionary Sexuality in Blake and Shelley', in 'And Never Know the Joy': Sex and the Erotic in English Poetry, ed. by C. C. Barfoot (Amsterdam: Rodopi, 2006), 189-206, at 193. 
33. The poem also has a significant biographical context, as Mary Shelley pointed out in her Introductory Note to her 1839 edition of Shelley's Poetical Works: 'In the Spring of 1815 an eminent physician pronounced that he was dying rapidly of a consumption; abscesses were formed on his lungs, and he suffered acute spasms. Suddenly a complete change took place; and though through life he was a martyr to pain and debility, every symptom of pulmonary disease vanished. His nerves, which nature had formed sensitive to an unexampled degree, were rendered still more susceptible by the state of his health', The Complete Poetry of Percy Bysshe Shelley, ed. by Donald H. Reiman, et al., vol. 3 (2012), 1067.

34. The Complete Poetry of Percy Bysshe Shelley, ed. by Donald H. Reiman, et al., vol. 2 (2004), 308, note 17.

35. Thomas Trotter, $A$ View of the Nervous Temperament, 2nd edn (London: Longman, et al., 1807), 164.

36. See Roy Porter, 'Death and the Doctors in Seventeenth-Century England', in Death, Ritual and Bereavement, ed. by Ralph Houlbrooke (London: Routledge, 1989), 77-94.

\section{SELECTED BibLIOGRAPHY}

Dormandy, Thomas. 1999. The White Death: A History of Tuberculosis. London: Hambledon Press.

Ford, Thomas H. 2018. Wordsworth and the Poetics of Air. Cambridge: Cambridge University Press.

Kay, Andrew. 2016. Conspiring with Keats: Toward a Poetics of Breathing. European Romantic Review 27/5: 563-81.

Lawlor, Clark. 2006. Consumption and Literature: The Making of the Romantic Disease. Basingstoke: Palgrave.

Meinecke, Bruno. 1927. Consumption (Tuberculosis) in Classical Antiquity. New York: Paul Hoeber.

O'Gorman, Francis. 2011. Coleridge, Keats, and the Science of Breathing. Essays in Criticism: A Quarterly Journal of Literary Criticism 61/4: 365-81.

Rose, Arthur, et al. 2019. Reading Breath in Literature. Basingstoke: Palgrave. Ruston, Sharon. 2013. Creating Romanticism: Case Studies in the Literature, Science and Medicine of the 1790s. Basingstoke: Palgrave Macmillan.

Stallybrass, Peter, and Allon White. 1986. The Politics and Poetics of Transgression. London: Methuen.

Vickers, Neil. 1997. Coleridge, Thomas Beddoes and Brunonian Medicine. European Romantic Review 8/1: 47-94. 
Open Access This chapter is licensed under the terms of the Creative Commons Attribution 4.0 International License (http://creativecommons.org/licenses/ by $/ 4.0 /$ ), which permits use, sharing, adaptation, distribution and reproduction in any medium or format, as long as you give appropriate credit to the original author(s) and the source, provide a link to the Creative Commons license and indicate if changes were made.

The images or other third party material in this chapter are included in the chapter's Creative Commons license, unless indicated otherwise in a credit line to the material. If material is not included in the chapter's Creative Commons license and your intended use is not permitted by statutory regulation or exceeds the permitted use, you will need to obtain permission directly from the copyright holder.

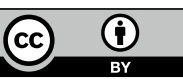

